\title{
Congenital stromal corneal dystrophy
}

INSERM

\section{Source}

INSERM. (1999). Orphanet: an online rare disease and orphan drug data base. Congenital stromal corneal dystrophy. ORPHA:101068

Cong enital stromal corneal dystrophy (CSCD) is an extremely rare form of stromal corneal dystrophy (see this term) characterized by opaque flaky or feathery clouding of the corneal stroma, and moderate to severe visual loss. 